\title{
The Role of Vitamin C Administration in Alleviation of Organ Damage in Rats Infected with Trypanosoma brucei
}

\author{
Ismaila A. UmAR, ${ }^{*}$ Zipporah A. ToH, Funnilayo I. IgBALAJobI, \\ Abubakar GIDADO, and Lawan B. BURATAI \\ Department of Biochemistry, University of Maiduguri, Maiduguri, Nigeria
}

(Received March 3, 1999)

\begin{abstract}
Summary The effect of vitamin C supplementation on the development of organ pathology in experimental Trypanosoma brucei infection in rats was investigated. Infection caused significant $(p<0.05)$ increases in serum alanine and aspartate aminotransferases as well as in blood urea nitrogen and serum creatinine. Infection also caused significant $(p<0.05)$ hypoproteinemia and hypoalbuminemia as well as decreases in liver and kidney total homogenate proteins. Supplementation of infected rats with vitamin $C$ prevented the disease-induced elevation of serum creatinine and alanine aminotransferase (ALAT) and also significantly ameliorated the decreases in total protein levels in serum, liver, and kidney, as well as the elevated serum aspartate aminotransferase (ASAT). The trypanosome infection caused depletion of the levels of reduced glutathione (GSH) in the blood, liver, and kidney, as well as reduced the plasma level of ascorbic acid. Vitamin supplementation prevented the depletion of these endogenous antioxidants. We concluded that vitamin $\mathrm{C}$ supplementation ameliorates oxidative stress, thereby sparing endogenous antioxidant reserves and protecting tissues and organs against $T$. brucei-induced damage.
\end{abstract}

Key Words: Trypanosoma brucei, organ pathology, vitamin C, rats

Human trypanosomiasis is still a major scourge on the African continent. The African sleeping sickness is caused principally by two Trypanosoma brucei subspecies, specifically $T$. gambiense and $T$. rhodesiense, which are mainly tissueinvading parasites [1]. The major pathological effects of the $T$. brucei groups are degenerative changes in vital tissues and organs of infected animals due to cellular injury [2]. Several factors have been implicated in trypanosome-induced cellular injury $[3,4]$, amongst which is oxidative stress [5] imposed by free radicals and

\footnotetext{
* To whom correspondence should be addressed.
} 
superoxides generated during trypanosomal infections $[6,7]$. These oxidative species attack polyunsaturated fatty acids of membrane phospholipids and membrane proteins [8] as well as cause depletion of systemic antioxidant reserves such as reduced glutathione (GSH) [9, 10] and ascorbic acid [11]. The antioxidant reserves provide protection for cellular macromolecules against oxidative agents.

The present investigation was therefore aimed at assessing the potential of vitamin $\mathrm{C}$ (an antioxidant) for reducing organ damage in T. brucei brucei infection of rats. T. brucei brucei infection of laboratory animals is often used as the experimental model for human trypanosomiasis.

\section{MATERIALS AND METHODS}

Animals. Twenty male Wistar strain rats weighing $140 \pm 26.75 \mathrm{~g}$ were divided into four groups of five rats each. All animals were allowed unrestricted access to a commercial feed (ECWA feeds, Jos, Nigeria) and drinking water.

Rats in group 1 were maintained as normal untreated controls, while those in groups 2 and 4 received daily oral doses of $100 \mathrm{mg}$ vitamin $\mathrm{C}$ (BDH Chemicals Ltd., Poole, England) per kilogram body weight as an aqueous solution throughout the duration of the experiment. Two weeks after commencement of vitamin supplementation, animals in groups 3 (not treated with vitamin C) and 4 were infected with T. brucei brucei (Basa Strain) by intraperitoneal injection of infected blood containing $10^{3}$ parasites from a donor rat. The parasites were obtained from the Nigerian Institute for Trypanosomiasis Research, Vom, Nigeria.

All animals were weighed weekly and food intake as well as parasitemia was monitored daily. The rats were sacrificed humanely by jugular decapitation with a sharp scapel at the end of the third week post-infection, and blood, serum, and plasma samples collected. Liver and kidneys were carefully extracted, blotted, and homogenized in distilled water. The organ homogenates were centrifuged at $3,000 \times g$ to obtain the supernatant, which was used for analyses of organ total proteins and GSH.

Methodology. Parasitemia was estimated in tail blood by the method described by Herbert and Lumsden [12]. Alanine aminotransferase (ALAT) and aspartate aminotransferase (ASAT) activities in serum were assayed with commercial reagent kits (Randox Laboratories, Ireland); and serum albumin, creatinine, as well as blood urea nitrogen, by the methods described by Tietz [13]. Plasma ascorbic acid was estimated according to Roe [14]. Serum and organ homogenate proteins were determined by the method of Reinhold [15] whereas GSH in whole blood and organ homogenates was estimated as described by Beutler et al. [16].

Analysis of data. Data were summarized as means \pm standard deviations, and differences between paired means were analyzed by Student's $t$-test. 


\section{RESULTS}

Parasitemia was detectable on wet blood smears of both infected groups on day 6, post-infection; and it progressively increased until the termination of the experiment. Similar parasitemias were recorded for the two infected groups (Table 1).

Infection with $T$. brucei without vitamin $\mathrm{C}$ supplementation caused significant $(p<0.05)$ increase in the serum level of ALAT and ASAT (Table 2) as well as significant decreases in serum total proteins and albumin. Administration of 100

Table 1. Parasitemias $\left(\times 10^{7}\right.$ parasites $/ \mathrm{ml}$ of blood) in $T$. brucei-infected rats with or without vitamin $\mathrm{C}$ treatment.

\begin{tabular}{ccc}
\hline \multirow{2}{*}{$\begin{array}{c}\text { Post-infection } \\
\text { time period (days) }\end{array}$} & \multicolumn{2}{c}{ Groups $(n=5)$} \\
\cline { 2 - 3 } & Infected control & Infected + vit. C \\
\hline 6 & $0.20 \pm 0.01$ & $0.20 \pm 0.03$ \\
11 & $0.29 \pm 0.03$ & $0.27 \pm 0.02$ \\
21 & $1.03 \pm 0.13$ & $1.57 \pm 0.62$ \\
& $2.93 \pm 0.65$ & $2.95 \pm 0.78$ \\
\hline
\end{tabular}

All values are means $\pm \mathrm{SD}$.

Table 2. Some serum and blood biochemical parameters of infected/noninfected rats treated/not treated with vitamin $\mathrm{C}$.

\begin{tabular}{|c|c|c|c|c|}
\hline \multirow{3}{*}{ Parameters } & \multicolumn{4}{|c|}{ Groups $(n=5)$} \\
\hline & 1 & 2 & 3 & 4 \\
\hline & Normal control & Normal + vit. C & Infected control & Infected + vit. C \\
\hline $\begin{array}{l}\text { Serum alanine } \\
\quad \text { aminotransferase }\end{array}$ & $\begin{array}{l}20.00 \pm 6.06^{\mathrm{a}} \\
\text { I.U./liter) }\end{array}$ & $26.00 \pm 10.46^{\mathrm{a}}$ & $49.50 \pm 13.80^{\mathrm{b}}$ & $28.00 \pm 6.38^{\mathrm{a}}$ \\
\hline $\begin{array}{l}\text { Serum aspartate } \\
\text { aminotransferase }\end{array}$ & $\begin{array}{l}69.50 \pm 10.30^{\mathrm{a}} \\
\text { I.U./liter) }\end{array}$ & $75.80 \pm 3.11^{\mathrm{a}}$ & $187.40 \pm 19.60^{\mathrm{b}}$ & $86.67 \pm 9.27^{c}$ \\
\hline $\begin{array}{l}\text { Serum total } \\
\text { proteins }(\mathrm{g} / \text { liter })\end{array}$ & $66.30 \pm 6.95^{\mathrm{a}}$ & $64.30 \pm 2.06^{\mathrm{a}}$ & $45.50 \pm 3.70^{\mathrm{b}}$ & $56.00 \pm 3.46^{\mathrm{c}}$ \\
\hline $\begin{array}{l}\text { Serum albumin } \\
\quad(\mathrm{g} / \text { liter })\end{array}$ & $40.50 \pm 6.70^{\mathrm{a}}$ & $39.50 \pm 3.87^{\mathrm{a}}$ & $32.75 \pm 3.78^{b}$ & $34.50 \pm 6.53^{\mathrm{ab}}$ \\
\hline $\begin{array}{l}\text { Serum urea } \\
\quad(\mathrm{mmol} / \text { liter })\end{array}$ & $2.38 \pm 0.96^{\mathrm{a}}$ & $4.90 \pm 0.39^{\mathrm{b}}$ & $5.80 \pm 1.12^{\mathrm{b}}$ & $5.14 \pm 1.38^{\mathrm{b}}$ \\
\hline $\begin{array}{l}\text { Serum creatinine } \\
(\mu \mathrm{mol} / \text { liter })\end{array}$ & $51.00 \pm 1.83^{\mathrm{a}}$ & $46.00 \pm 4.97^{\mathrm{a}}$ & $70.60 \pm 12.23^{\mathrm{b}}$ & $51.50 \pm 12.40^{\mathrm{a}}$ \\
\hline $\begin{array}{l}\text { Plasma ascorbic } \\
\text { acid (mmol/liter) }\end{array}$ & $0.066 \pm 0.010^{\mathrm{a}}$ & $0.065 \pm 0.005^{\mathrm{a}}$ & $0.032 \pm 0.009^{\mathrm{b}}$ & $0.060 \pm 0.003^{a}$ \\
\hline $\begin{array}{l}\text { Blood glutathione } \\
(\mathrm{mmol} / \text { liter })\end{array}$ & $1.20 \pm 0.23^{\mathrm{ac}}$ & $0.93 \pm 0.26^{\mathrm{ab}}$ & $0.69 \pm 0.05^{b}$ & $1.34 \pm 0.26^{\mathrm{c}}$ \\
\hline
\end{tabular}

All values are means \pm SD. Comparison was done along the rows, and different superscripts indicate values that are statistically different $(p<0.05)$.

Vol. 28, No. 1, 2000 
Table 3. Some biochemical parameters of organs from infected/noninfected rats treated/ not treated with vitamin $\mathrm{C}$.

\begin{tabular}{|c|c|c|c|c|}
\hline \multirow{3}{*}{ Parameters } & \multicolumn{4}{|c|}{ Groups $(n=5)$} \\
\hline & 1 & 2 & 3 & 4 \\
\hline & Normal control & Normal + vit. C & Infected control & Infected + vit. C \\
\hline \multicolumn{5}{|c|}{ Total proteins $(\mathrm{mg} / \mathrm{g})$} \\
\hline Liver & $119.92 \pm 26.06^{\mathrm{a}}$ & $215.70 \pm 34.24^{\mathrm{b}}$ & $87.00 \pm 14.66^{c}$ & $94.85 \pm 19.81^{\mathrm{a}}$ \\
\hline Kidney & $107.39 \pm 62.36^{\mathrm{ab}}$ & $163.55 \pm 10.66^{\mathrm{a}}$ & $69.49 \pm 24.78^{b}$ & $85.74 \pm 24.73^{\mathrm{b}}$ \\
\hline \multicolumn{5}{|c|}{ Glutathione (mg/g protein) } \\
\hline Liver & $0.92 \pm 0.13^{\mathrm{a}}$ & $0.89 \pm 0.11^{\mathrm{c}}$ & $0.51 \pm 0.46^{\mathrm{b}}$ & $0.78 \pm 0.14^{\mathrm{c}}$ \\
\hline Kidney & $1.20 \pm 0.39^{\mathrm{a}}$ & $0.97 \pm 0.13^{\mathrm{ac}}$ & $0.40 \pm 0.09^{\mathrm{b}}$ & $0.88 \pm 0.16^{\mathrm{c}}$ \\
\hline
\end{tabular}

All values are means \pm SD. Comparison was done along the rows, and different superscripts indicated values that are statistically different $(p<0.05)$.

$\mathrm{mg}$ vitamin $\mathrm{C} / \mathrm{kg}$ body weight to infected rats completely prevented the diseaseinduced increase in the ALAT level in the serum and significantly $(p<0.05)$ alleviated the increase in ASAT level and the decrease in serum total protein consequent to infection. Treatment with vitamin $\mathrm{C}$, however, did not alleviate the T. brucei-induced hypoalbuminemia. Significant $(p<0.05)$ increases in blood urea nitrogen (BUN) and serum creatinine (Table 2) were recorded in unsupplemented infected animals. The serum creatinine level of vitamin-treated infected animals was similar to that recorded for healthy animals, whereas the BUN was still at the infection level despite the vitamin supplementation. The levels of blood GSH and plasma ascorbic acid (Table 2$)$ in infected rats were significantly $(p<0.05)$ lower than those recorded for healthy rats, and vitamin supplementation of infected animals maintained the blood GSH and plasma ascorbic acid levels at normal levels.

T. brucei infection caused significant $(p<0.05)$ decreases in total proteins and GSH in kidney and liver homogenates (Table 3) of the rats. Supplementation of infected rats with vitamin $\mathrm{C}$ significantly alleviated $(p<0.05)$ the disease-induced decreases in these parameters.

\section{DISCUSSION}

T. brucei infection of the rats caused significantly increased serum levels of ALAT and ASAT, which confirms earlier reports $[17,18]$. Increases in the levels of these enzymes are indications of damage to liver, brain, and cardiac muscles [19], and several workers have reported hepatocellular damage and generalized degenerative changes in other tissues and organs in trypanosomiasis $[2,20]$. Hypoproteinemia and hypoalbuminemia observed in this work were also reported earlier [21] and were attributed to proteinuria [20] and hepatocellular damage [22] that occur during trypanosomiasis. Supplementation with vitamin C completely prevented the disease-induced increase in ALAT and significantly alleviat- 
ed the increase in ASAT as well as the decreases in serum total proteins and albumin in the infected rats. These findings suggest that the vitamin had protected the liver, and possibly other organs, against the disease-induced degenerative changes.

BUN and serum creatinine levels were significantly elevated during the course of infection, which confirmed reports of other workers [23, 24]. Increased BUN indicates increased protein breakdown due to muscle wasting observed in trypanosomiasis as well as reduced excretion due to renal damage. Reduced glomerular filtration due to glomerular lesions leads to increased levels of creatinine in the serum [19]. Glomerulonephritis and damage to other renal structures have been consistently reported to occur in experimental infections with trypanosomes [25]. Though vitamin $\mathrm{C}$ administration prevented the disease-induced elevation of serum creatinine, it had no effect on the elevated level of serum urea, and so the increased breakdown of body protein caused by the infection was not affected by the presence of the vitamin, hence the persistent high levels of serum urea. It is pertinent to note here that vitamin supplementation did not affect the level of parasitemia. The prevention of the elevation of serum creatinine caused by infection may indicate protection of renal structures against degenerative processes due to trypanosome activities.

Oxidative damage to tissues and organs during trypanosomal infections is presumably due to membrane damage caused by the large amounts of free radicals and other oxidative species being generated and the concomitant reduction in systemic antioxidant reserves, as was confirmed by the observed significant reduction in blood, liver, and kidney levels of glutathione as well as by that in plasma ascorbic acid in the infected, unsupplemented rats in this experiment. The prevention of organ damage by vitamin $\mathrm{C}$ is predicated on its antioxidant activity [26]. Presumably the vitamin aided in quenching the free radicals being generated by trypanosome activity, thereby drastically reducing the systemic free radical load as well as having a sparing effect on other systemic antioxidants. The sparing effect of vitamin supplementation on blood, liver, and kidney glutathione as well as on plasma ascorbic acid (both endogenous antioxidants) was thus confirmed in this experiment.

We thus concluded that supplementation with vitamin $\mathrm{C}$ ameliorates organ damage during $T$. brucei infection of rats. The data lend further support to the significant roles of oxidative stress and depletion of endogenous antioxidant reserves in the organ pathogenesis of African trypanosomiasis.

We mention with gratitude the Nigerian Institute for Trypanosomiasis Research, Vom, Nigeria, for providing the parasite.

\section{REFERENCES}

1. Losos, G.J. (1979): Infections caused by African trypanosomes, in Pathogenicity of Trypanosomes. Proceedings of a Workshop Held at Nairobi, Kenya, 20-23 November, 1978, ed. by

Vol. 28, No. 1, 2000 
Losos, G., and Chouinard, J.A., IDRC Publ., Ottawa, Canada, pp. 59-62.

2. Anosa, V.O., and Kaneko, J.J. (1984): Pathogenesis of T. brucei infection in deer mice (P. maniculatus). Ultra structural pathology of the spleen, liver, heart and kidney. Vet. Pathol., 21, 229-237.

3. Newton, B.A. (1979): The metabolism of African trypanosomes in relation to pathogenic mechanisms, in Pathogenicity of Trypanosomes. Proceedings of a Workshop Held at Nairobi, Kenya, 20-23 November, 1978, ed. by Losos, G., and Chouinard, A., IDRC Publ., Ottawa, Canada, pp. 17-22.

4. Zwartz, D., and Veenendaal, G.H. (1979): Pharmacologically active substances in T. vivax infections, in Pathogenicity of Trypanosomes. Proceedings of a Workshop Held at Nairobi, Kenya, 20-23 November, 1978, ed. by Losos, G., and Chouinard, A., IDRC Publ., Ottawa, Canada, pp. 111-113.

5. Igbokwe, I.O. (1994): Mechanisms of cellular injury in trypanosomiasis. Vet. Bull., 64, 611615.

6. Askonas, B.A. (1985): Macrophages as mediators of immunosuppression in murine African trypanosomiasis. Curr. Top. Microbiol. Immunol., 117, 119-127.

7. Vray, B., De Baetselier, P., Ouaissi, A., and Carlier, Y. (1991): Trypanosoma cruzi but not T. brucei fails to induce a chemiluminescent signal in a macrophage hybridoma cell line. Infect. Immun., 59, 3303-3308.

8. Slater, T.F. (1984): Free radical mechanism in tissue injury. Biochem. J., 222, 1-15.

9. Ameh, D.A. (1984): Depletion of reduced glutathione and the susceptibility of erythrocytes to oxidative hemolysis in rats infected with T. brucei gambiense. IRCS J. Med. Sci., 12, 130.

10. Igbokwe, I.O., Lafon, J.Y., Umar, I.A., and Hamidu, L.J. (1988): Erythrocyte and hepatic glutathione concentrations in acute T. brucei infection of rats. Trop. Vet., 16, 81-83.

11. Roskin, G.I., and Nastiukova, O. (1941): Vitamin C in the protozoic cell. Competes Rendus (Dok-lady) De L'Academic des sciences de L'U.R.S.S., 32, 566-568.

12. Herbert, W.J., and Lumsden, W.H.R. (1976): Trypanosoma brucei: A rapid "matching" method for estimating the host's parasitaemia. Exp. Parasitol., 40, 427-431.

13. Tietz, N.W. (1982): Fundamentals of Clinical Chemistry, W.B. Saunders, Philadelphia, pp. 280-283.

14. Roe, J.H. (1973): Ascorbic acid (Vit. C) in blood and urine. Proc. Soc. Exp. Biol. Med., 37, 465 .

15. Reinhold, J.G. (1953): Estimation of plasma total proteins and albumin, in Standard Methods in Clinical Chemistry, Academic Press, N.Y., pp. 88-90.

16. Beutler, E., Duron, O., and Kelly, B.M. (1963): Improved method for the determination of blood glutathione. J. Lab. Clin. Med., 61, 882-888.

17. Moon, A.P., Williams, J.S., and Witherspoon, C. (1968): Serum biochemical changes in mice infected with T. rhodensiense and T. duttoni. Exp. Parasitol., 22, 112-121.

18. Singh, D., and Gaur, S.N. (1983): Biochemical changes associated with T. evansi infected buffalo calves. Indian J. Anim. Sci., 53, 195-196.

19. Kaplan, L.A., Szabo, L.L., and Opheim, E.K. (1988): Enzymes, in Clinical Chemistry: Interpretation and Techniques, 3rd ed., Lea and Febiger, Philadelphia, pp. 182-184.

20. Bruijn, J.A., Oemar, B.S., Ehrick, H.H., Foidart, J.M., and Flueures, G.J. (1987): Antibasement membrane glomerulopathy in experimental trypanosomiasis. J. Immunol., 139, 24822485.

21. Kalu, A.U., Ikwuegbu, O.A., and Ogbonnah, G.A. (1989): Serum protein and electrolyte levels during trypanosome infection and following treatment in the West African Dwarf goats. Bull. Anim. Health Prod. Afr., 37, 41-45.

22. Ingh, T.S.G.A.M., Van der Zwart, D., Miert, A.S.J.P., Van, A.M., and Schotman, A.J.H. (1976): Clinico-pathological and pathomorphological observations in T. vivax infection in cattle. Vet. Parasitol., 2, 237-250.

23. Hudson, J.A. (1944): Acute and subacute trypanosomiasis in cattle caused by T. vivax. J. Comp. Pathol., 54, 108-119. 
24. Sadun, E., Johnson, A., Nagle, R., and Duxbury, R. (1973): Experimental infections with African trypanosomiasis. V. Preliminary parasitological observations in rhesus monkeys infected with T. rhodesiense. Am. J. Trop. Med. Hyg., 22, 228-230.

25. Murray, M., Lambert, P.H., and Morrison, W.I. (1975): Renal lesions in experimental trypanosomiasis. Medicine et Maladies Infectieuses, 12, 638-641.

26. Anderson, R., and Theron, A.J. (1990): Antioxidant and tissue protective function of ascorbic acid, in World Review of Nutrition and Dietetics, Vol. 62, ed. by Borne, G.H., S. Krüger, N.Y., pp. 37-38. 